\title{
Sakinah Family Concept Based on Jama'ah Tabligh Perspective (Jaulah) in Indonesia
}

\author{
Wirdatuz Zahro' Afifah Ridwan \\ Fakultas Syariah UIN Maulana Malik Ibrahim Malang \\ Luthfiati.zafiroh@yahoo.com
}

\begin{abstract}
Abstrak
This research is field research, descriptive and uses qualitative approach. To get the data, researcher uses 3 data collection methods are observation, interview and documentation. The results of this research, it was found that sakinah family concept based on Jama'ah Tabligh is family that is led by husband who works in $d a$ 'wah religion sincerely and all the members of family feel peace, always run the commands of Allah and the Sunnah of his Messenger as well as, practice obligatory and sunnah deeds then make Prophet family as minimal model. All member of family must support and remind each other, practice the religion perfectly and always get the blessing of God. they efforts in create sakinah family are by giving religious education for their children, reinforcing the faith, practicing deeds, implementing khuruj fi sabilillah program for husband and masturoh programs to wife regularly, always keeping the communication between husband and wife, discussing to solve the problem. In other hand, member of family should be able to keep other deeds like doing $d z i k r$, recitating, reading important surah like surah Yasin in the morning and doing the duties and obligations as a husband-wife especially educate children and always Istiqomah in charities.
\end{abstract}

Penelitian ini merupakan penelitian lapangan, bersifat deskriptif dan menggunakan pendekatan kualitatif.Untuk memperoleh data peneliti menggunakan tiga metode pengumpulan data, yakni observasi, wawancara dan dokumentasi. Hasil dari penelitian ini, ditemukan bahwa makna keluarga sakinah menurut Jama'ah Tabligh adalah keluarga yang dipimpin oleh seorang suami yang bekerja dalam da'wah agama secara ikhlas dan seluruh anggota keluarga merasakan ketenangan, selalu menjalankan perintah Allah dan sunah Rasul-Nya serta mengamalkan amalan fardhu dan sunnah serta menjadikan keluarga Rasul sebagai suri tauladan dalam membentuk keluarga sakinah. Seluruh aggota keluarga harus saling mendukung juga dan saling mengingatkan satu sama lainnya, bisa mengamalkan agama secara sempurna serta selalu mendapat ridho dari Allah. Adapun upaya mereka dalam membentuk keluarga sakinah yaitu dengan memberikan pendidikan agama untuk anak-anaknya, mempertebal iman, mengamalkan amalan, melaksanakan program khuruj fi sabilillah untuk suami dan program masturoh untuk istri secara rutin, selalu menjaga komunikasi antara suami istri, musyawarah keluarga dalam menyeleseikan masalah. Selain itu. Anggota keluarga tersebut harus bisa menjaga amalan-amalan sunah lainnya seperti dzikir, tilawah, membaca surat penting, membaca surat yasin di pagi hari dan melaksanakan tugas dan kewajiban sebagai seorang suami istri terutama dalam mendidik anak serta selalu Istiqomah dalam beramal.

Key words: sakinah concept; Islamic family; Jaulah. 


\section{Introduction}

A family is the smallest unit within society that has the function of creating a peaceful life, safety, peace, and prosperity and love and affection among its members. A life bond based on marriage can be also be found in mothering or parenting behavior. ${ }^{1}$ Community experts argue that home is first place both men and women form their personal identities. If this place is clear and free from any negativity, then it will be safe to form a personality without destructive qualities. A strong family is a family that can create the next quality generation with strong character. They then become constructive members of society finally creating a glorious nation. The family is an institution as a vehicle for creating a peaceful, safe life, safe, and together they can be prosperous. ${ }^{2}$ In a country, a family is like a seed. If that seed is good, then it will be fertile and produce leaves and dense fruit. ${ }^{3}$ One family model that the Prophet used was sakinah, mawaddah warahmah family. Sakinah family terms are explained in the words of Allah SWT in Qur'an surah ar-Rum verse 21 that marriage is an external and internal bond, with the aim to create a happy household- sunny, peaceful, and eternal. ${ }^{4}$ A Sakinah family could be called an ideal household. It means the household is built on a foundation of faith and the contentment of God always refers to the Qur'an and asSunnah when conflict is happening and standing on the principles of peace, love, affection and far from the noise and hustle..$^{5}$ The ideal household is built based on the principle of sakinah, mawaddah warahmah. The House will be a dwelling place of character-building for the personality of the child. There are some factors of an ideal household, they are: personality-related conditions, feelings and relationships between individuals within the family; relating to economic issues and financial management; and everything that relates to general thoughts on a brilliant domestic life. ${ }^{6}$

A family can be called a sakinah family if it has fullfiled several criteria, namely: piety (obey commandments of Allah and his Prophet); religious knowledge (deeply studying and learning Islam); keeping family healthy; financial responsibility (spending less than the income) and harmonious relationships within the family. ${ }^{7}$ The sakinah family can be a pillar of of the community forming the ideal society which it can give birth to a pious generation. A strong generation will be born from a Sakinah family, because it includes values such as love, affection, commitment, responsibility, mutual respect, togetherness, and good communication. A family based on values will be the optimal place for children to grow and develop. ${ }^{8}$ One formation of the sakinah family concept is the ideal relationship between a husband and wife based on "mua'syarah bi al-Ma'ruf" (the good association for the husband and wife $)^{9}$ which is explained in surah an-Nisa'(4) verse 19. Mu'asyarah is a relationsip of friendship, family, togetherness, kinship and familiarity while ma"ruf is customary, habitual or culture (something that is well-known). ${ }^{10}$ In surah an-Nisa verse 19 we learn that God wants a good marriage to be built on a pattern of positive interaction, harmony, and peaceful

\footnotetext{
${ }^{1}$ Mufidah Cholil, Psikologi Keluarga Islam Berwawasan Gender (Malang: UIN-Malang Press, 2013 ), 37.

${ }^{2}$ Husein Muhammad, Fiqh Perempuan Refleksi Kiai Atas Wacana Agama Dan Gender (Yogyakarta: LKiS, 2007), 121.

${ }^{3}$ Nur Hidayati, “Konsep Keluarga Sakinah Perspektif Aktivis Hizbut Tahrir Malang” (Magister Thesis, UIN Maulana Malik Ibrahim Malang, 2009), 2.

${ }^{4}$ QS.Ar-Rum (30) : 21

${ }^{5}$ Butsainah al-Sayyid al-Iraqi, 1000 Cara Membahagiakan Suami Istri, trans. Ahmad Saminto and Mustofa (Yogyakarta: Mitra Pustaka, 2006), 116-17.

6 Muhammad Ustman al-Khusyt, Membangun Harmonisme Keluarga, trans. Lembaga Penerjemah Penulis MuslimIndonesia (Jakarta: Qisthi Press, 2007), 39-40.

${ }^{7}$ Aziz Mushoffa, Untaian Mutiara Buat Keluarga (Yogyakarta: Mitra Pustaka, 2001), 12-13.

${ }^{8}$ Hidayati, "Konsep Keluarga Sakinah Perspektif Aktivis Hizbut Tahrir Malang," 3.

${ }^{9}$ Cholil, Psikologi Keluarga Islam Berwawasan Gender, 117-118.

${ }^{10}$ Muhammad, Fiqh Perempuan, 106.
}

Jurisdictie: Jurnal Hukum dan Syariah Vol. 6 No. 2 Desember 2015 
hearts. It should also be marked by the balance of rights and obligations between them. Moreover, for a husband is the head of family. He is responsible for his family members and everything associated with the family. It is related to jasādiyah, rūhiyah,or ,aqliyah. ${ }^{11}$

Husain Syahatah" in his book "Ar-Rajul wa Al-Bait baina Al-Wajib wa Al-Waqi" (translated by Faizal Asdar Bakri as "responsibility of the Husband in the household") explains that there are eight responsibilities of a husband to his wife in Islam as well as the responsibility of a wife to her husband. If the husband or wife fulfill their responsibilities well then goodness and blessings materialize in their Muslim household thus creating a Sakinah family: peaceful, safe, affectionate, and soft. There are many ways for a Muslim family to build a Sakinah, mawaddah warahmah family. Someone who has no wealth can feel the harmony, peace and happiness in their life. Happiness and creation of a Sakinah family cannot be bought. Analogous with the role of the sakinah family in creating quality generations that facilitate the progress of a nation, there is a group of Muslims who move in the Da'wah (preaching) department. They are struggling to spread and teach Islam as the Prophet taught it. They want to bring back the heyday of Muslims as in the time of the Prophet and teach the practice of dzikr to Muslims-Jama'ah Tabligh.

Jamaeah Tabligh is a group that is established by a sufi of the tariqah Jisytiyyah Maturidiyyah faith and uses a Hanafi Fiqh scholar. He is Muhammad Ilyas Ibn Ismā'îl Muhammad Al-Hanafi Al-Diyubandi Al-Jisyti Al-Kandahlawi Ad-Dihlawi. Al-Kandahlawi, which is a nisbat name of Kandahlahwi which is a village located in the Sahranfurarea. AdDihlawi is attributedto the Capital of India, New Delhi. There is a Jama "eah Tabligh movement there. Ad-Diyubandi is the nisbat of Diyuband, and is the biggest school of Hanafi scholar followers in the peninsula of India. Al-Jisyti is attributed to the Al-Jisytiyah which is Sufism. That is established by Mu'inuddin Al-Jisyti. Muhammad Ilyas was born on $1303 \mathrm{H}$ as Akhtar Ilyas. His family followed the Al Jitsytiyyah Al-Shufiyyah thariqat. He was a hâfidh (memorized the Quran) and studied at Diyuband school studying under Professor of Thariqat, Shaykh Rashid Ahmad Al-Katskuhi. He died on 11 Rajab 1355 H (Bis Bri Musliman, p. 583, Sawanih Muhammad Yusuf, p. 144- 146, taken at Jama'atut of Talbligh Yajibu's Tushahhah Mafahim, p.2). ${ }^{13}$ Jama'ah Tabligh is a popular group in Malaysia. In Pakistan, it is wellknown as Al-Jamaa'ah At-Tablighiyah or Al-Jama'ah Al-Ilyasiyah. In Indonesia is known as Jaulah / Jama'ah Tabligh. In the Tablighi Dustur al-' Amal page 3, It is explained that the purposes of Jama'ah Tabligh are to elevate the word of God, spreading tabligh Islam and unity infaith and make improvements to scholars and related teaching methods (ta'lim). ${ }^{14}$

The Members of Jama'ah Talbligh are required to do khuruj fi sabilillah (preaching) at least once in their lifetime and it is recommended once a year.The purpose of their da'wah is to build Muslims with the khuruj concept which strongly emphasizes the construction of the suluk aspect/akhlaq, certain forms of worship, such as dzikr, piety, and patience. ${ }^{15}$ It teaches the practices that they believe had been taught by the Prophet such as women wearing the veil, men preaching to spread Islam. Jama'ah Tabligh is one of the Islamic groups that have the sakinah family model. Jama'ah Tabligh has many followers in the Kediri area. It has been

\footnotetext{
${ }^{11}$ Kiswatun Nidha, "Konsep Keluarga Sakinah Menurut Jama"ah Tabligh Perspektif Hukum Islam," accessed December 17, 2012, http://teosufi.webs.com/apps/blog/show/14112493-konsep-keluarga-sakinah-menurut-jamaah-tabligperspektif-hukum-islam-,.

${ }^{12}$ Husain Syahatah and Faisal Asdar Bakri, Tanggung Jawab Suami Dalam Rumah Tangga, 1st ed. (Jakarta: Media Grafika, 2005), 14-23.

${ }^{13}$ Abdul Rahman Haji Abdullah, Pemikiran Islam Di Malaysia: Sejarah dan Aliran (Jakarta: Gema Insani, 1997), 77-80.

${ }^{14}$ Sayyid Ahmad Syihab al-Din qadi Kalyakut, Menyingkap Tabir Jamaah Tabligh, trans. Teungku H. Hasanoel Bashry (Yogyakarta: Diandra Primamitra Media, 2008), 18.

15 Abu Salma Al-Atsari, "Studi Kritis Pemahaman Jama"ah Tabligh Dan Kitab Taghlibi Nisab," accessed December 7, 2012, http://varyd.wordpress.com/membongkar-kedok-jamaah-tabligh-2/.

Jurisdictie: Jurnal Hukum dan Syariah Vol. 6 No. 2 Desember 2015
} 
developing for 23 years. Jama'ah Tabligh have had four halaqoh (central colleges) that are spread out in Kediri. Da'wah is a special characteristic of spreading Islam. Therefore, a husband must go out to preach and during that time he has to leave his family. In every khuruj fi sabilillah, they leave their families anywhere from three days to forty days and sometimes up to one year. Before they practice khuruj fi sabilillah, usually they collect some money for preparing khuruj and for their family left behind.They think that jihad needs a sacrifice of treasure and lives for people. Seeing this situation, sometimes their existence is not liked by the community. The society argues that leaving their family to preach is wrong because they leave their obligations as a husband, as the head of the family and bread winner. Looking at this condition, this article aims to discribe what a sakinah family concept is based on the Jama"eah Tabligh perspective and to describe the efforts of Jama"eah Tabligh to establish a sakinah family.

\section{Research Method}

This research was conducted in Kediri, specifically in the Campurejo and Petok region as a gathering place for Jama'ah Tabligh members. Both Campurejo and Petok are halaqoh places for Jama'ah Tabligh members. Usually, the members of Jama'ah Tabligh gather in sessions of majelisan (special events). There are many followers of Jama'ah Tabligh in this area. In the Petok region, the Jama'ah Tabligh members's houses are neighboring. In Kampung Dalem - Kediri, there are many groups of Jama'ah Tabligh that live close together. Sometimes, one family is a group of Jama'ah Tabligh followers. Campurejo was specifically chosen as locus of this research, because many of Tabligh beginners live there. This article based on field research to describe a sakinah family concept based on Jama'ah Tabligh and their efforts in creating the sakinah family. The approaches used in this research are the socioapproach, the religious approach, the educational background approach and the ideology approach (religious understanding) of Jama'ah Tabligh. The researcher would interview the informants thoroughly about their socio condition, their understanding of Jama'ah Tabligh, their understanding of the sakinah family concept and their efforts to create a sakinah family based on da'wah.

\section{Result and Discussion}

\section{The Description of Jama'ah Tabligh in Kediri}

Jama'ah Tabligh is an Islamic group that hasmany members all over Indonesia and the world. Jama'ah Tabligh began in Kediri in 1991, through a member of Jama'ah Tabligh from Kertosono. He started khurujto Babatan (Banyakan to the West, the Regency of Kediri). From the beginning, many of societies and village administrations received him. Then in 1998, Jama'ah Tabligh grew in Kediri and in2001expanded to Petok-Mojo. In Tabligh, there is no term for Jama'ah members or leaders or organization, because the leader is just at the center and the system is organized. Every region there is a responsible, while in Kediri there are three halaqoh (the development place of Jama'ah Tabligh). The responsible person in the Babatan region is Mr.Kholid. In Kediri there is Mr. Din and Mr. Khoirul. In the Petok region there is Mr. Amami. And now the Jama'ah Tabligh has expanded to theKandat - Wates region and the responsible man there is Mr. Ahmad Abdul Wahid. Syuriah Leader Center is led by Mr. Cecep. The members of Jama'ah Tabligh have increased and are countless. The specific characteristic of Jama'ah Tabligh are the khuruj fi sabilillah program for husbands. If he is able a husband can take three days for khuruj fi sabilillah and the masturoh program for wives which is implemented every 3-4 months. The implementation will be discussed first. Jama'ah Tabligh considers among members of Jama'ah Tabligh as partners of da'wah. 


\section{Sakinah Family Based on Jama'ah Tabligh Perspective}

The Sakinah family is an effort of every family to create a happy, peaceful and harmonious family. To create it, every family musthave science as a financial capital, one of them is the knowledge of sakinah family based on Jama'ah Tabligh. To know what a sakinah family is based on Jama'ah Tabligh, the writer got the information by interviewing as follows: Sakinah family according to Mrs. SH is:

"Keluarga sakinah adalah Jika suami bekerja di dalam dakwah agama dengan konsentrasi kuat lahir batin, ikhlas, dan tidak ada pamrih apa-apa. Maka seluruh keluarga, anak, istri amalan dan sikapnya dari bangun tidur hingga tidur kembali yang dirasakan hanya ketenangan nikmat semua itu dari Allah. Ketika suami keluar untuk berdakwah maka anak-anak tidak akan bersikap berlebihan dan tidak akan mengikuti emosi dan ambisi nafsunya."

EK adds that the sakinah family was:

"Saling mendukung agama dan saling mengingatkan"

A family is considered sakinah if a family is led by a husband who works in da wah (preaching) sincerely and can make all the members of the family feel comfortable if they have donesunnah deeds and support each other. The context of religious $d a$ 'wah is more importantthan any other aspects. In addition, the support of family is also the most important thing for creating asakinah family. Mrs. DH said that:

"Insya Allah kalau orang beriman yang dicontoh itu Kanjeng Nabi.Kanjeng Nabi itu suatu contoh keluarga sakinah yang sudah menjadi tolok ukur kita tetapi yang menjadi pegangan kita bukanlah dari televisi, keluarga artis atau keluarga jenderal"

Then, Mrs. YK adds that sakinah family was:

"Keluarga yang bisa mengikuti sunah-sunah Rosul, hidup sunah. Insya allah kalau sudah menghidupkan sunah Rosul dalam keluarga, maka akan sakinah."

$\mathrm{Hj}$. $\mathrm{CH}$ also expressed same opinion about sakinah family was:

"Mengamalkan amalan, kita juga mengkaji tentang fadhailul amal dalam masturoh. Ketika kita mendapat ilmu sedikit dari masturoh tadi lalu kita aplikasikan dan diamalka. Kalau belum mengamalkan rasanya tidak enak. Seperti membaca sholawat, wiridan, surat-surat penting kalau belum diamalkan serasa mengganjal dalam hati. Seumpama kita tidak sempat melakukan amalan tersebut karena ada udzur syar'i, maka kita punya tanggungan untuk mengqodho'nya. Kita berusaha istiqomah."

Then, Mrs. SU delivered her same opinion with previous informant that sakinah family is:

"Kalau saya merasakan keluarga sakinah dalam keluarga saya apabila keluarga saya semua bisa amal agama secara sempurna, yang bisa mendatangkan ketenangan di dalam rumah. Jadi setiap anak saya mengamalkan amalan itu sudah merupakan kebahagiaan dan ketenangan tersendiri buat kami. Kesakinahan dalam keluarga saya itu bahwa ahli sekeluarga dapat mengamalkan secara sempurna seperti yang dibawa oleh Rasulullah. Jadi dalam kehidupan sehari-hari bisa menerapkan walau tidak bisa semuanya, berusaha semaksimal mungkin bagaimana

Jurisdictie: Jurnal Hukum dan Syariah Vol. 6 No. 2 Desember 2015 
agar dalam keluarga saya dapat wujud seperti rumahnya para sahabat yaitu mengamalkan agama, di rumah ada taklim, ada bacaan qur'an, ada dzikir, sholat dsb itu sudah merupakan sakinah yang tiada bandingannya. Kalau masalah keduniaan saya tidak merasa risau. Sehingga pokoknya kita sekeluarga dapat mengamalkan agama secara sempurna maksudnya yaitu berusaha untuk menyempurnakan amalan-amalan. Misal dulu jarang sholat rowatib, setelah itu saya punya program agar tetap bisa mengerjakan amalan-amalan sunnah walau sesibuk apapun. Seumpama ketika saya mau keluar, maka saya akan sholat awal waktu agar saya tetap bisa menjalankan amalan lain seperti biasanya. Sakinah dalam keluarga saya itu saya artikan ketenangan, kebahagiaan. Kebahagiaan keluarga saya, saya ukur apabila saya sebagai orang tua mengupakan agar anakanak saya dapat beramal agama, berusaha mendidik anak-anak saya apa yang diperoleh di pondok tetap diamalkan dalam rumah. Saya merasa tenang ketika kedua orang anak saya sudah hafidz, menjadi seorang ustadz serta memahami agama. Dan Kami orang tua juga berusaha menjadi figur yang baik bagi anakanak kami. Dan terkadang anak-anak juga mengingatkan orang tua ketika melakukan hal yang salah. Saya merasa senang. Dengan anak saya diberi paham agama, maka dia bisa mengingatkan saya. Jadi dalam keluarga bisa saling mengingatkan. Saya mengutip dari QS. At-tahrim ayat 6 bahwa jagalah dan selamatkanlah keluargamu dari api neraka. Selain itu, saya juga mengingatkan anak-anak saya untuk mengingatkan saudara-saudaranya yang berbuat salah dan mengajak kepada kebaikan. (dapat beramal agama, beramal dengan sunah Rasul)."

According to the subjects above, the definition of a sakinah family is a family that is a reflection of our Prophet's life; follows the messenger deeds; practices the obligatory and sunahdeeds as well as studying the book. The best family example is The Messenger family for Muslims who built a sakinahfamily. Furthermore, we must always practice the obligatory (fardhu) and sunah deeds in our dailylife to attain comfort and peace in the family. Then, that all must be supported by reading the holy book in the masturoh program that is based on the Fadhailul 'Amal book. On the masturoh activity, the wives of Jama'ah Tabligh learn, study and deepen their knowledge of how be a sholehah wife, a good mother, how to educate her children, and communicate with the society and others. Another subject, Mrs. YL had different opinions about the sakinah family:

"Dengan ikut agama, ikut perintah Allah, ikut sunnah Rasulullah itu sakinah. Karena Rasulullah sendiri juga sudah mencontohkannya kepada keluarganya. Jadi seorang istri itu mempunyai tanggung jawab dalam rumahnya, mendidik anaknya, ketaatan pada suaminya juga termasuk tuntunan dari agama. Kita mencari contoh seperti sahabat Rasul, Rasulullah jadi tidak perlu kita mencari contoh kayak orang seorang dari tetangganya. Tapi kita mencari ontoh suri tauladan dari Rasulullah yang diajarkan kepada para sahabatnya"

Then, Mrs. Hj. JZ adds a bit that sakinah family was:

"Istri harus taat kepada suami, rukun dengan keluarga"

Mrs. NA also agreed with an earlier informant that:

"Suatu keberkahan lah dan Kemudahan"

And Mrs. SR also stated that: 
"Keluarga yang diridhoi Allah, jika Allah ridho maka akan diberi kesakinahan, ketentraman jiwa. Untuk mendapat ridho Allah dengan mentaati perintah dan menjauhi larangan-Nya, beramal. Apa yag diridhoi Allah insya allah akan memberikan sakinah dalam diri kira, keluarga kita"10

From the above statement it can be concluded that themeaning of a sakinahfamily is thefamily whose members understand religion, obey Allah and his Messenger and with a wife who obeys her husband and is blessed by God. The meaning of Sakinahis a blessing and easiness for the members of a family. In creating a sakinah family, the couples must understand each other and know how to implement the rights and obligations of husbandwife. Their responsibilities are asa husband or father and as wife or mother. Then, couples should help and remind each other if their partner is wrong or neglects a responsibility. As the members of Jama'ah Tabligh, their duties are important not only inda'wah, but also they have a responsibility as the head of the family and as the wife. The head of the family has an obligation to earn a living, lead a household, and provideeducationto the children and his wife. $\mathrm{He}$ is the main responsible person, a leader and someone who is always protecting his family. But on the other hand, a head of a family has an obligation to do khuruj fi sabilillah from three days up to four months even up to one year to build the religion of Allah, broadcast Islam and invite other Muslimsto worship.

Therefore, the author wants to know how the husband fulfills his obligations as a husband when he must do khuruj fi sabilillah. The answers are as follows: Mrs. SH argued about the obligations of the husband when her husband must do khuruj:

"Ibu jadi single parent karena sudah ada perjanjian sebelum suami khuruj. Kalau ditinggal beberapa hari, maka saya butuh beberapa mal yang mana saya tidak bisa saya cari jika tidak ada maka nanti ada stok/penggantinya untuk pengganjal. Kalau tidak ada maka saya tidak izinkan untuk khuruj. Karena saya belum bisa, setiap doa saya langsung dikabulkan Allah. Karena sesuai kerepotannya. Karena dakwah itu mengorbankan harta, diri. jadi harus ada persiapan nafkah untuk keluarga yang ditinggal khuruj itu. Minimal 50\% persen keperluan kita sudah dipenuhi suami. Keajaiban setiap ditinggal khuruj, setiap saya menangis setiap saya berdoa Allah akan datangkan apa yang saya inginkan"

The opinion above is similar that is described by Mrs. DH that:

"Alhamdulilah karena dalam keseharian sudah biasa terbagi. Karena ibu yang otomatis harus 24 jam di rumah maka ibu menjadi kepala rumah tangga sedang suami tetap menjadi kepala keluarga. Lalu ketika keluar menjadi alih fungsi, sehingga saya mengemban amanat tersebut. Tetapi selama kita mampu mengerjakanya itu menjadi double fungsi tapi kalau tidak bisa dikerjakan sendiri maka saya meminta bantuan yang diwakili teman abinya (seperti kalau ada kerusakan sanyo). Jadi walapun ditinggal tetap ada musyawarah markas. Kalau nafkah lahir ya seikhlasnya kalau dikasih alhamdulilah kalau tidak ya alhamdulilah. Tapi ketika mau khuruj mesti tetap dikasih jatah sesuai dengan kemampuan suami tidak sampai di luar kemampuan suami. Umpama ketika seorang suami punya bisnis air isi ulang, maka istri tidak perlu angkat-angkat air galon tersebut dan bisa menjadi tambahan untuk memenuhi kebutuhan yang mendadak. Atau kita yang mempunyai keahlian menjahit bisa disambi menjahit atau bordir. Kalau nafkah batin karena kita sudah terbiasa ditinggal suami khuruj. Justru kadang-kadang temen-temen itu lebih suka kalau suami tidak di rumah, sedih kalau di rumah. Karena dirasa hiburan yang halal bagi suami adalah istri karena dengan ditinggalnya khuruj, kita bisa mengamalkan amalan, ngaji satu juz,"

Jurisdictie: Jurnal Hukum dan Syariah Vol. 6 No. 2 Desember 2015 
Mrs. $\mathrm{Hj} . \mathrm{CH}$ argued that:

"Kalau bapak keluar, otomatis kita mendukung. Masalah kebutuhan ketika hidup pas-pasan maka kita harus menerima."

A similar thing is also expressed by Mrs. Hj. JZ:

"Saya merasa tidak keberatan dalam hal mendidik anak. Mungkin karena anak saya sudah besar-besar yang paling kecil ya yang masih MTs itu. Yang kecil juga nggak mau kemana-mana.biasanya jam 8-9 aja sudah tidur. Waktu liburan aja anak saya tidak pernah maen mungkin kalau ada temannya yang ngajak main baru dia keluar. Kalau masalah nafkah alhamdulilah cukup. Ada toko bahan bangunan yang sudah diserahka ke saya. Jadi kalau ada apa-apa saya bertanggung jawab sendiri"

Mrs. NA said that:

"Kalau dalam jama'ah begini mbak, jadi ada musyawarah antara suami dengan istri. Untuk pemberangkatan itu harus ada persiapan dan istri itu bagaimana sudah siap apa belum suami sudah siap apa belum kalau sudah siap semua maka suami berangkat. Dan teman-teman insya allah ada yang datang untuk ishrof"

Mrs.YL also gave a little argue about the obligation of husband when the husband do khuruj (about giving a necessity, as the leader of household, educating children and others) that:

"Kalau dalam penerapan di rumah saya, sebelum keluar sudah direncana dulu. Jadi kita tidak melepaskan tanggung jawab. Jadi segala urusan mengenai muamalah, masalah anak dan semuanya diselesaikan dulu karena ada tenggang waktunya. Jadi kita sudah tahu nisab untuk keluar itu bulan apa. Jadi jauh-jauh hari kalau ada masalah, maka masalah itu diselesaikan dulu. Seperti masalah kebutuhan anak, pembayaran spp anak sudah diperhitungkan. Jadi kita tidak langsung meninggalkan keluarga $f i$ sabilillah. Ya dipikirkan sebelumnya, diselesaikan dulu masalahnya. Kalau tanggung jawab anak, ibu juga mempunyai tanggung jawab di dalam rumah juga ayah. Kalau keluar fi sabilillah, abi juga dalam penjagaan Allah. Jadi kalau kita niatnya sungguh-sungguh dalam membela agama Allah, insya Allah, Allah akan menjaga pula yang di rumah. Karena dalam fadhilahnya rumah orang yang diitinggal khuruj akan dijaga 500 malaikat. Tidak mungkin anak istrinya terlantar. Rumah akan merasa lebih aman. Kita harus yakin akan pertolongan Allah. Karena orang sekarang ini keyakinannya sudah luntur, jadi kalau kita ini ditinggal beberapa hati itu sudah dilatih berkeyakinan hanya kepada Allah, yang dimintai harapan segalanya yakin kepada Allah. Ketika sudah ada bapaknya maka merasa sudah aman dan bergantung ke bapaknya dan menyepelekan akan pertolongan Allah serta tidak meminta berharap kepada Alah. Hal itu dapat menambah keyakinan ketika ditinggal khuruj. Alhamdulillah ketika ditinggal abinya khuruj, Allah tidak pernah memberikan saya cobaan yang memberatkan saya. Tujuan itu hanya sekedar saja."

A similar explanation is also explained by Mrs. YK that:

"Kalau seorang suami itu keluar tergantung istrinya. Kalau istrinya ikhlas insya allah tidak apa-apa. Kalaupun ada kesusahan, masalah keuangan atau apapun, ada tidaknya suami kalau Allah menghendaki ya masih aja. Tapi kalau istri itu ikhlas, percaya dan berdoa kepada Allah insya allah tidak ada kendala apa-apa. Ya ikhlas ketika bapaknya keluar di jalan Allah. Mengenai nafkah lahir batin,

Jurisdictie: Jurnal Hukum dan Syariah Vol. 6 No. 2 Desember 2015 
kalau kita paham bahwa nafkah lahir itu bisa direncanakan sedangkan batin kan dari kesabaran. Kayak hubungan suami istri itu kan tidak mungkin ditinggalkan selamanya kayak orang yang ditinggal kerja selama 2 tahun aja tidak apa-apa apalagi kalau sekedar hanya ditinggal 40 hari ya tidak apa-apa. Itu aja paling lama 4 bulan dan tidak terus menerus ditinggal. Mendidik anak itu seperti memberi contoh tidak mendidik secara langsung harus melakukan apa yang kita suruh. Anak sekarang kan sudah pinterpinter dan modern. Misalnya saja jilbab ketika kita mau keluar, kita harus memberi contoh menggunakan jilbab. Kalau bergaul juga gitu, seumpama aja ketika di kampung anak-anak akan main dengan anak laki-laki, maka kita akan memanggilnya agar tidak sering main dengan anak perempuan. Sholat juga begitu, membiasakan sholat di awal waktu itu sulit maka ibunya harus membangunkan, mengingatkan dan cerewet terus"

Mrs. EK argued about the obligations of a husband when khuruj:

" Ketika suami keluar ya tetap memberi nafkah tinggalan. Kan saya juga sedikit bisa bantu kekurangannya. Saya juga bisa bekam walaupun tidak setiap hari tapi setiap satu minggu itu ada sedikit pemasukan. Dan dari saudara-saudara ada isrof atau bantuan juga ada. Kalau pendidikan anak satunya sekolah di MI satunya masih TK." Mrs. SU gave little argument about the duties and obligations of husband when he doeskhuruj fi sabilillah,: "alhamdulilah sejak suami saya dikenalkan dengan dakwah walaupun tidak sesukses dibanding orang-orang yang ahli dunia. tapi saya menganggap sukses usaha suami dibandingkan sebelum ikut usaha dakwah. saya dulu punya karyawan banyak. saat itu saya punya usaha kerupuk. tapi alhamdulilah sejak kita ikut dakwah, ekonomi kita berangsur-angsur ditata oleh allah. saat suami saya keluar semua masalah kebutuhan insya allah sudah terpenuhi dan dicukupi. usahanya sekarang adalah pedagang parfum. alhamdulilah walaupun seberapa saya bisa cari sendiri. jadi untuk menunjang kekurangan suami. saat ditinggal, suami kan meninggalkan jatah untuk anak-anak untuk uang saku, dan mungkin di saat abahnya keluar ada kebutuhan mendadak maka sebelumnya abahnya akan pesan semisal uangnya nanti kurang maka ambil aja uangnya di konter-konter penitipan parfum. Saya merasa semakin ditata oleh Allah."

Mrs. SR gave additional arguments about the obligations of husbands when doing khuruj fi sabilillah as follows:

"Suami memang pemimpin rumah tangga, mendidik anak adalah kewajibannya tetapi ibu adalah madrasah pertama bagi anaknya dan suami hanya mengecek saja. Maka ibu yang menggantikan karena Suami juga punya kewajiban kerja. Kalau masalah nafkah dhohir, belanja itu sudah ada ukurannya sesuai dengan kemampuan. Kalau nafkah jasmani sesuai denga kemampuannya. Kalau nafkah rohani tidak bisa digambarkan. Agama sebenarnya nafkah rohani. Kalau ditinggal khuruj itu nafkah rohaninya semakin meningkat. Seorang istri akan meminta kepada Allah, bergantung kepada Allah"

When the husband has to khuruj fi sabilillah then the wife will hold a double function, as the head of household and as the mother. About the obligation of living costs, wives have similarly argued that before doing khuruj, all needs of the family were left to be resolved early by their husbands (daily necessities, education/monthly payments, electricity bills, and other needs). Husbands will give living costs for their families' needs while they are khuruj and the wives should be sincere to receive a living cost that has been given to themby their husbands. Mrs. SU argued that by knowing da'wahshe feels that their families need economic are given Jurisdictie: Jurnal Hukum dan Syariah Vol. 6 No. 2 Desember 2015 
by God is enough. According to the obligations of educating children, Mrs. SR and Mrs. Yunita argued that the wives have an obligation to educate their children too. Mothers are the first teachers for their children, and they should be able to be a good model for their children and give religious education beginning at an early age. The result of the interviews proved that there are some differences of understanding of a sakinah family based on Jama'ah Tabligh. Then, we can divide it into the following groups:

\begin{tabular}{|c|c|c|}
\hline Informant & Understanding of Sakinah Family & Aspect \\
\hline $\begin{array}{l}\text { - Mrs. DH } \\
\text { - Mrs.YK } \\
\text { - Mrs.CH } \\
\text { - Mrs.SU }\end{array}$ & $\begin{array}{l}\text { Husband who works at preaching religion } \\
\text { sincerely and all members of family feel } \\
\text { calm and comfortable after practice the } \\
\text { deeds. }\end{array}$ & $\begin{array}{l}\text { Preaching and practice the } \\
\text { deeds }\end{array}$ \\
\hline $\begin{array}{l}\text { - Mrs. DH } \\
\text { - Mrs.YK } \\
\text { - Mrs.CH } \\
\text { - Mrs.SU }\end{array}$ & $\begin{array}{l}\text { Prophet's family as good model to us } \\
\text { (follow and turn on the prophet deeds); } \\
\text { practice deeds; reading Fadhailul 'Amal. }\end{array}$ & Deeds and education \\
\hline $\begin{array}{l}\text { - Mrs. YL } \\
\text { - Hj. JZ }\end{array}$ & $\begin{array}{l}\text { Follow the religion; obey to Allah and } \\
\text { prophet's command also to her husband; } \\
\text { Prophet's family as good model and } \\
\text { harmonious. }\end{array}$ & Understanding of Religion \\
\hline $\begin{array}{l}\text { - Mrs. NA } \\
\text { - Mrs. SR } \\
\text { - Mrs. EK }\end{array}$ & $\begin{array}{l}\text { a blessing and easy; always is blessed by } \\
\text { God and always support and remind each } \\
\text { other. }\end{array}$ & Family and God's blessing \\
\hline
\end{tabular}

From the results of the interviews conducted by the writer, the understanding of Jama'ah Tabligh's wives is quite satisfied. There are some subjects who still had difficulty in answering some questions when the writer asked them about the meaning of a sakinah family. Their answers tended to depend on their educational backgrounds. Most of them are Senior High School graduates and did not have experience other in non-formal education such as studying at an Islamic boarding school or a religious school. There are some difference answer about sakinah family understanding. Most of them give sakinah family is based on religious understanding that they get from masturoh program.

\section{The Efforts of Jama'ah Tabligh in Create Sakinah Family}

The data of these interviews was gathered by the author from observations of respondents. We know that every family has different supporting and obstacle factors in creating a sakinah family. Mrs. SH and Mrs. SR said that:

"Faktor pendukung : iman (karena dengan iman kita dapat hidayah agar semangat untuk mencari ilmu. Ingin mengetahui mana yang baik dan buruk. Seperti di Jama'ah tabligh ini, ada program kursus yang disebut dengan masturoh yang merupakan program diskusi khusus bagi perkumpulan istri Jama'ah Tabligh mengenai hak kewajiban suami isteri, mendidik anak secara sunnah, dan bagaimana membentuk keluarga sakinah, khitmat kepada suami, dll. Program ini juga sudah dijadwal dan ditentukan waktunya. Dengan program ini semakin kita mempunyai ilmu), sholat, amalan-amalan sunnah yang disunnahkan Rasulullah (amalan pagi petang, baca surat yasin dan itu dirasa manfaatnya banyak), pendidikan, ilmu (Karena orang yang berilmu akan menjadi tahu bagaimana akan membentuk keluarga sakinah, karena banyak juga orang yang tidak berilmu keluarganya malah berantakan. Walau banyak harta kalau tidak berilmu ya sama 
saja. Lalu, faktor pendukung lainnya yaitu amal. Serta jika Suami istri paham agama mengamalkan agama secara sempurna insya allah sakinah dunia akhirat).

Faktor penghambat: cobaan itu selalu ada. Bukankah setan itu datang sesuai dengan tingkatan iman manusia. Makanya semakin besar iman kita kepada Allah, maka setanpun semakin banyak cara menggoda untuk tidak melakukan amalan itu. Penghambatnya selalu nafsu (nafsu ada 2 yaitu Nafsu haq dan jelek). Diarahkan ke arah yang benar atau yang salah, maka ada 2 alternatif. Kita mau perang atau tidak dengan hati kita. Kalau mau perang, otomatis setan akan kalah. Semakin besar tingkatan iman kita semakin besar pula cobaan yang kita hadapi. Dan walaupun sudah punya ilmu tapi kalau nafsunya masih tinggi, seirng banyak menuntut sehingga keluarga itu merasa risau dan masih keduniaan. Kalau orag sudah lama ikut Jama'ah Tabligh dan paham ajaran agama insya allah tidak banyak menuntut. Kalau wanita itu terjun ke dakwah seperti siti khodijah yang mengorbankan hartanya untuk dakwah suami. Tapi bagi saya kalau bisa mengorbankan harta untuk urusan dakwah merasa mendapat kebahagiaan dan tidak bisa diukur. Karena sebenarnya kita membelanjakan harta di jalan Allah bukan untuk siapa-siapa melainkan untuk diri sendiri".

Every family that will build a sakinah family should have supporting and inhibiting factors. The supporting factors in creating a sakinah family are faith, prayer, sunnah of the Prophet, education and science. It means every member of the family must remind and invite the others to join in prayer, practice sunnah deeds and seek knowledge. Because by gaining knowledge, we will understand more and know how to create a sakinah family, give the best education for children, preach in God's way and other things. In the aspect of educating children, the members of Jama'ah Tabligh have specific religious programs for each member of the family. In this program, all members of the family will gather in a room and their parents will give a subject of science (learning to read/understanding religion/ memorizing the holy Koran and other things). These activities are routine activities for 1-2 hours every day. While the biggest inhibiting factor in a family is lust, or desire. Another subject, Mrs. DH, said that in creating a sakinah family should have supporting and inhibiting factors, such as:

"Faktor Pendukung: jelas ada dari pihak keluarga saya atau keluarga suami saya. Pengamalan agama lebih matang seperti menggunakan jilbab. Kalau dulu mau pergi ke walimahan ya baru tutup aurat. Alhamdulilah setelah mengenal dakwah, pengamalan agama lebih dirasa perlu. Memakai hijab itu ternyata perintah yang harus dilaksanakan di saat hati senang atau tidak senang.

Faktor Penghambat : Kalau dari keluarga saya, karena dulu dari pendidikan umum jadi pola pikirnya anaknya sekolah tingkat tinggi, agamanya yang penting tidak ketinggalan. Tapi setelah kenal dakwah ini alhamdulilah agama itu harus lebih dipentingkan dari umum. Saya dan suami sebenarnya sama-sama basicnya dari umum. Kalau masalah keduniaan semua keluarga suami sukes. Keluarga juga merasa kecewa, karena saya tidak mempergunakan ilmu yang saya dapatkan di tingkat universitas. Dan saya pun tidak berpikir untuk menyekolahkan anak sampai tingkat tinggi kerja lalu dapat penghasilan. Pendidikan umum itu memang perlu tapi perlu disetir dengan agama."

Similar things are also suggested by $\mathrm{Hj}$. $\mathrm{CH}$ and Mrs. YL

"Faktor Pendukung :dari pihak suami, pihak keluarga. Insya allah kalau kita mengikuti sunah Rasul, kita hidup dalam kesederhanaan. Jadi kalau hidup sederhana itu memudahkan dalam segala hal. Contohnya saja kalau makan saja,

Jurisdictie: Jurnal Hukum dan Syariah Vol. 6 No. 2 Desember 2015 
kita makan bareng-bareng malah mempermudah kita. Kita tidak butuh banyak waktu untuk mencuci piring. Kalau makannya model prasmanan, nanti malah banyak menambah pekerjaan, membutuhkan biaya banyak, memakan banyak waktu

Faktor Penghambat : Insya Allah tidak ada. Karena dipermudahkan dalam segala hal."

Mrs.Hj. JZ, Mrs. Emy Kurniawati and Mrs. Yunita Kurniana also agreed with the earlier subject that:

"Faktor Pendukung: - dari pihak keluarga. - rasa menerima karena saya menerima apa adanya dari suami. Suami memberi rizqi sedikit diterima banyak ya juga diterima dan selalu sabar ketika ditinggal khuruj oleh suami. - mengerti dan memahami agama sebenarnya. Agama yang benar itu yang mengikuti sunnah Rosul yang sebenarnya. Paham betul apa yang agama itu ajarkan. Tapi kalau faktor pendukung dari orang lain, insya allah malah tidak bisa awet. Seperti omongan-omongan dari orang itu biasanya masih bisa goyah.

Faktor Penghambat : - insya allah tidak ada hambatan. Karena alhamdulilah saya sih menerima saja kalo dikasih. Mungkin dulu saya juga pernah merasakan saya orang yang tidak punya. Saya dulu orang yang biasa-biasa saja mbak. Saya aja sekolah Cuma SD. Saya merasa cukup aja sejak abah itu pekerjaannya masih kuli bangunan. Alhamdulilah saya dan keluarga saya diberi kecukupan. Saya juga melihat orang di bawah saya, alhamdulillah saya masih bisa makan - Insya allah kalau bapak ibu sudah sepaham insya allah tidak ada kendala."

From the explanation above, it can be concluded that the supporting factors to create a sakinah family are: family support, practice the sunnah of the Prophet, knowing and understanding the religion and always receive the family condition and be patient in facing all trials. The wives of Jama'ah Tabligh were certain that by practicing the deeds of the Prophet in daily life, it will create a sakinah family. Besides that, as a wife and as a mother, women should be receptive and patient in their current situation. It means they can be invited in difficult or happy situations, can receive the giving of a husband, be patient in family difficulty such as economic difficulties, and if they are excommunicated by their family/friends/neighbors/society. In creating a sakinah family, they argued that they did not find any obstacles in reaching a sakinah family. Mrs. DH stated that there are some of her family who were unhappy with their activities at Tabligh. Mrs. DH assumes that her family's mindset is still worldly and is disappointed in her, because she doesn't want to use her science knowledge that she attained at a university level. Other subjects who disagreed with the previous subject include Mrs. NA, who argued that:

"Faktor Pendukung: anak-anak yang mendukung. Kadang-kadang ada anak yang tidak menerima juga ada.

Faktor Penghambat : dari pihak keluarga yang belum paham agama ya menentang mbak. Cuma kalau keluarga saya meskipun menentang nggak ada suara hanya diam. Ya menerima tapi tidak mengikuti. "

Mrs. SU who agreed with Mrs. NA, said that:

"Faktor Pendukung: alhamdulilah dari keluarga saya, saat saya memilihkan pendidikan anak-anak saya ke pondok di jurusan tahfidz itu saudara saya dan ibu saya sangat mendukung. Bentuk dukungannya tidak hanya dengan ucapan tetapi juga memberi uang saku terkadang ketika anak saya pulang dari pondok. Tetap ada perhatian. Dan alhamdulilah dari keluarga suami yang awalnya menentang 
dan membenci saya dan suami akhirnya lambat laun mendukung pendidikan anak saya dan perhatian.

Faktor Penghambat : jelas ada. Terutama dari keluarga. Dalam membentuk keluarga sakinah, memang saya rasakan dapat menentramkan hati. Oleh Allah saya diberi keluarga itu memang dari atas aspek kita ini dakwah. Pada saat kita mengambil usaha dakwah, kalau keluarga saya walaupun belum ada yang ikut alhamdulilah tidaka da yang menghambat. Tapi dari keluarga suami beberapa ada yang menghalangi, dari tetangga, teman kita dikucilkan di masyarakat. Itu hal biasa dan wajar. Lalu saya berpikir Rasulullah yang sudah maksum saja masih diberi cobaan kayak gitu apalagi kita orang awam yang begini. Pokoknya saya istiqomah pada Allah, pasti akan diganti oleh Allah."

This is in contrast to the previous informant who thought that the supporting factor in this family is from supporting their children and part of their families. The form of support from family is by providing material and/or non-material support in choosing their children's education such as giving extra money or prayer. While the constraints on their family are from family members who don't understand religion fully, and the excommunication from families, neighbors and the local community. In building a sakinah family, every family has different constraints and supporting factors. Thus, every family has tricks or attempts to create a sakinah family. There were two informants who were inclined to support more religious education:

"Saya dibiasakan menjadi single parent di rumah. Single parent mendidik anakanak bagaimana anak bisa belajar agama, belajar ilmu. untuk mendapatkan ilmu itu harus dikelola dari sekolah, pondok, mengaji, target hafalan, target qur'an harus diprogram. Karena saya pernah mendengar bahwa pendidikan sebenarnya bukan pendidikan dari pondok pesantren/sekolahan tetapi dari dalam keluarga. Sehingga orang tua harus menunjang program pendidikan dari luar yang benar untuk dilakukan."(Mrs.SH)

"Usaha saya, saya sebagai ibu. Ibu adalah madrasah pertama bagi anak-anaknya. Saya harus berani menjadi contoh bagi anak-anak saya. Saya juga harus berhatihati sungguh-sungguh terutama ketika anak-anak masih kecil kan suka meniru tingkah laku orang tuanya. Maka sejak anak-anak kecil sebelum saya kenal dakwah sudah saya kenalkan agama. Saya ajari ngaji sendiri, saya ngajikan di pondok. lalu kita pantau, kita ajak ketika sudah tiba waktu sholat. Intinya bahwa seorang ibu adalah peranan utama untuk menjadikan keluarga itu menjadi keluarga yang sakinah. Karena bagaimanapun pola pikir seorang ibu itu akan membentuk wataknya anak. Kalau ibu cenderung ke keduniaan maka anak itu akan cenderung pola pikir dan tingkah lakunya ke keduniaan juga. Dan sebaliknya. Jadi sejak kecil, anak-anak sudah saya kenalkan agama, ibu harus berani menjadi contoh kita didik anak untuk belajar agama. Saya sekolahkan ke diniyah dan memantau perkembangan belajar. Saya berlaku keras dalam hal ibadah, misal kalau tidak mau sholat duha saya tidaka akan memberi uang saku, kalau tidak mau mengaji nanti saya pukul. Dan kita selalu mengawasinya. Ketika anakanak paham agama, kita harus arahkan dan mempraktekkannya serta mengamalkannya walapun tidak semua kita dapat mengamalkannya."(Mrs.SU)

From the explanation above, we know that the efforts by Mrs. SH and Mrs. SU are for education development. It means that how mothers can give the best education for their children the most important thing is religious education at an early age. Therefore, a mother's role is needed. If the mother is the main teacher of her children, then she must provide a good Jurisdictie: Jurnal Hukum dan Syariah Vol. 6 No. 2 Desember 2015 
model for her children. The mother should always monitor her child's development in their learning and worship. They must be serious in their worship, after that the mothers give direction when they have really understood and can practice their deeds. Other subjects have different opinions about the efforts of creating a sakinah family:

"Mempertembal imam, mengamalkan amalan. Adanya program khuruj bagi suami dan masturoh bagi istri. Komunikasi suami istri harus tetap dijaga, sering musyawarah, pendidikan kita terhadap anak termasuk juga proses kita menuju keluarga sakinah. Seandainya seorang anak tidak mau sekolah tapi mau mengaji maka ngajinya itu yang diutamakan. Pembentukan sifat dari situ. Terkadang anak itu ada yang dapat menguasai keduanya (pengetahuan agama dan umum) dan ada pula yang condong ke satu bidang (lebih ke agama, tidak mau sekolah)." (Mrs. DH)

"Usaha saya yatu menjaga amalan-amalan rumah jadi seperti Rasulullah kepada para sahabat, wanita sholehah itu mengikuti amalan-amalan. Selain dia menjaga amalan fardhu ditambah lagi dengan amalan sunnah atau amalanamalan lainnya tentang dzikir, tilawah, membaca surat penting, membaca surat yasin di pagi hari insya allah akan dicukupi kebutuhan kita sampai sore hari juga termasuk menambah ketemtraman keluarga. Kalau ada masalah lalu kita selesaikan dengan amalan insya allah ya cepat selesai." (Mrs. YL)

"Istiqomah dalam amal. Karena dengan merasakan istiqomah itu seperti anakanak istiqomah ibadahnya maka keluarga merasakan sakinah dan tentram dan merasa kaya. walaupun tidak punya uang tetap tentram hatinya."(Mrs. SR) "Meminta petunjuk Allah. Mendidik anak secara sunnah, mengamalkan amalan sunnah. Yang sunnah itu diamalkan insya allah akan terbentuk keluarga sakinah. Termasuk taat kepada suami, taat kepada Allah juga akan membentuk keluarga sakinah."(Mrs NA)

It can be concluded that the efforts of the wives of Jama'ah Tabligh in creating a sakinah family are strengthening the faith, practicing charity, following and implementing a khuruj fi sabilillah program for the husband, and a masturoh program for the wife. Then, communication must exist between the husband and wife, by having discussions when they have problems and giving religious education to their children by sunnah. Mrs. YL adds that by keeping the practices of sunnah, the obligatory practices and other practices such as dzikr, reciting Holy Koran, reading important surah, and reading the surahYasin in the morning are efforts that are needed to reach a sakinah family. The practice of deeds should be done more, according to Mrs. Rofiqoh. After that, we ask for God's guidance in order to guide the family to always be protected and blessed by God. There are some subjects who have different opinions from the previous subjects, they tend to a regular program of $d a$ 'wah every year:

"Kita belajar lagi kalau ada masturoh, disitu akan diadakan muzakarahmuzakarah tentang kehidupan rumah tangga, mendidik anak, patuh pada suami. Kalau soal ekonomi meminalisir agar tidak boros." (Mrs. Hj.CH)

"Usaha saya yatu menjaga amalan-amalan rumah jadi seperti Rasulullah kepada para sahabat, wanita sholehah itu mengikuti amalan-amalan. Selain dia menjaga amalan fardhu ditambah lagi dengan amalan sunnah atau amalanamalan lainnya tentang dzikir, tilawah, membaca surat penting, membaca surat yasin di pagi hari insya allah akan dicukupi kebutuhan kita sampai sore hari juga termasuk menambah ketemtraman keluarga. Kalau ada masalah lalu kita selesaikan dengan amalan insya allah ya cepat selesai." (Mrs. Hj. JZ)

Jurisdictie: Jurnal Hukum dan Syariah Vol. 6 No. 2 Desember 2015 
"Mulai dari belajar lalu diterapkan sedikit demi sedikit. Jadi usaha nya dengan belajar lalu dipraktekkan."(Mrs. YL)

"Tetap belajar agama dengan masturoh itu juga usaha dengan teman-teman. Isnya allah nanti kalau istri paham agama juga bisa mendidik putranya, taat kepada suami dan bisa menerima kelebihan dan kekurangannya. Intinya kita harus paham agama." (Mrs. EK)

According to the explanation above, we know that following amasturoh program is one of the efforts to create a sakinah family. By following masturoh actively, we can learn more deeply about many things, especially related to the household like how to be a pious wife, how to obey the husband, and how to educate the children. After we get a little science in the masturoh program, then we practice it in daily life. So, the wife can understand the religion and know how to educate children, obey her husband and can accept her husband's strengths and weakness. From the masturoh program, the wife can have various experiences and can share that knowledge with others. There are some efforts that is done by informants to reach sakinah family.

\begin{tabular}{|c|c|c|}
\hline Informant & The Effort tp Creating Sakinah Family & Aspect \\
\hline $\begin{array}{l}\text { - Mrs. SH } \\
\text { - Mrs.NA } \\
\text { - Mrs.SU }\end{array}$ & $\begin{array}{l}\text { educate the children; practice the deeds; } \\
\text { ask the guidance of God; religion } \\
\text { education }\end{array}$ & education \\
\hline - Mrs. DH & $\begin{array}{l}\text { Reinforce the faith, practice the deeds, do } \\
\text { preaching program (khuruj fi sabilillah and } \\
\text { masturoh), give education, keep } \\
\text { communication and have discussion. }\end{array}$ & Religion understanding \\
\hline $\begin{array}{l}\text { - Mrs. YL } \\
\text { - Hj. JZ } \\
\text { - Mrs. CH } \\
\text { - Mrs. EK }\end{array}$ & Follow masturoh; study at masturoh; & masturoh \\
\hline - Mrs. YL & $\begin{array}{l}\text { Keep the deeds and always be istiqomahin } \\
\text { charitable. }\end{array}$ & religion \\
\hline
\end{tabular}

From the explanation above, we can conclude that there are some similarity and difference of sakinah family characteristic based on Jama'ah Tabligh and The Ministry of Religious Affair, in following:

\begin{tabular}{|l|l|}
\hline \multicolumn{1}{|c|}{ Jama'ah Tabligh } & \multicolumn{1}{|c|}{ Religious of Ministry Affair } \\
\hline Legal marriage & $\begin{array}{l}\text { Fulfill the criteria of First Sakinah } \\
\text { (legal Marriage) }\end{array}$ \\
\hline $\begin{array}{l}\text { Accustomed to pray together and } \\
\text { pray at early time }\end{array}$ & Accustomed to pray together; \\
\hline Have a decent place to live & Administrator of organization; \\
\hline Do the obligatory and sunnah deeds & Have a decent place to live; \\
\hline $\begin{array}{l}\text { Giving education for member of } \\
\text { family in every day }\end{array}$ & $\begin{array}{l}\text { understanding the importance of } \\
\text { family health; }\end{array}$ \\
\hline Life simple and sufficiency & Harmonious; \\
\hline Pleasure to give shadaqah and infaq & Pleasure to give a shodaqah; \\
\hline Good understanding of religion & Do the qurban; \\
\hline $\begin{array}{l}\text { Preaching family (husband does } \\
\text { khuruj fi sabilillah and wife does }\end{array}$ & $\begin{array}{l}\text { Member of Family are able to } \\
\text { fulfill the tasks and obligation of }\end{array}$ \\
\hline
\end{tabular}

Jurisdictie: Jurnal Hukum dan Syariah Vol. 6 No. 2 Desember 2015 


\begin{tabular}{|l|l|}
\hline masturoh program) & each other; \\
\hline $\begin{array}{l}\text { The minimum formal education is } \\
\text { senior high school and islamic } \\
\text { boarding school at Temboro, } \\
\text { Magetan }\end{array}$ & High School. \\
\hline $\begin{array}{l}\text { Use long robe (jubah) for husband } \\
\text { then use a long gamis and purdah } \\
\text { (cadar) for wife. }\end{array}$ & \\
\hline Husband's job average is trader. & \\
\hline
\end{tabular}

The writer analyzes that by the sakinah family criteria of the Ministry of Religious Affairs, the subjects inclined to create a KS III (KS stands from sakinah family). KS III is a family that can fulfill faith, devotion, good character, social psychological such as education necessities, religious guidance within the family, joining the religious social interactions within their environment and development of family (being able to comprehend and develop faith values, devotion, good character, infaq, zakat, charity, and savings), but it is not yet capable to be a good model for the environment. The characteristics of KS III according to the Ministry of Religious Affairs, are: a. Fulfill the criteria of First Sakinah (legal Marriage); b. Accustomed to pray together; c. Administrator of organization; d. Have a decent place to live; e. Understanding the importance of family health; f. Harmonious; g. Pleasure to give a shodaqah; h. Do the qurban; i. Family is able to fulfill the tasks and obligations of each other; j. The minimum Education is Senior High School.

From the explanation above, it can be concluded that the subjects refer to KS III. In regards to educational background, the majority of the subjects' highest level of education was Senior High School. Most did not have a non-formal educational background such as religious schools or Islamic boarding schools. They did not understand the religious education and they were influenced easily by other new organization. It is evident when the writer asked them about Jama'ah Tabligh. Most of them just follow this group and consider it to be the best group among others because by this group they have to invite other Muslims to worship, always pray together, do all the commands of God and the Prophet and keep away from God's prohibitions and practice the deeds and sunnah deeds. For them, life is to preach to look for supplies in the hereafter and not only for worldly things. KS III is a family that is formed from legal marriage and fulfills KS II criterias such as praying, fasting, paying alms, giving infaq, learning the fundamentals of religion, reciting the holy Koran, having responsibilities to society, and fulfilling the nutritional needs of their family.

KS III gives attention to religion education and formal education until the Senior High School level. This sakinah family learns the base of religion from reciting the holy Koran until they always practice the deeds in their daily life. From the economic aspect, the average job ofsubjects husbands were traders (gold traders, perfumes, crackers, honey and herbal medicines, the business of re-content of water. The median of their incomes is enough to fulfill their daily needs (eating, extra money for children, paying electricity and others) and the cost of tuition. Several subjects are not only house wives but also they have other skills such as sewing, bekam or managing their husband's business. Some subjects work to help the income of the family as much as possible, too. From this aspect, we know that the lives of the subjects are very simple and enough for their daily needs. They want to live like the Prophet and are more concerned with religious importances than worldly. They do not want to work like a usual person, live for work, but they believe that the sustenance is set up by God and every child who is born will bring their own fortune. In the aspect of children's education, they more frequently choose for their children to have religious education. Most of the 
subjects want their children to study and learn in Islamic boarding schools after they finish their education in Junior High School or Senior High School.

They want their children to study at the Islamic boarding schools of Temboro, Magetan to memorize the Holy Koran. They do not think about sending their children to University because, to them, the most important education is religious education. The children do not rebel and complain to their parents, they just follow what their parents want. Because they know the socio-economic condition of their parents will always be enough and sufficient for a simple life until they cannot send them to higher education. In addition, the family of Jama'ah Tabligh has to fulfill social-psychology need such as educational needs, religious guidance, and havinga good interactions with family, neighbors and their community. In religious guidance, they always give religious education to their children everyday from basic education until to a higher level. When they have a problem or are restless then they will go to other members of Jama'ah Tabligh or to a scholar for consultation and discussion to get the best solution to solve their problem.

The religious social interaction with their surrounding environment is well enough, it's just that their existence is often disliked and they are even excommunicated by society. In fact, when there are guests who are visiting their home, then they will try to serve their guest based on ikromul dhuyuf, though maybe only a glass of water. They treat their guests very well and welcome others when they need their help. Although they have no money, they are still happy and are never sad. A family can be called a Sakinah Family if a husband and wifeunderstand and know their duties and obligations. Understanding and implementing the rights and obligations as husband and wife according to Islamic law must be done by them as well, and they must be able to keep a harmonious family by maintaining the harmony of their family and communicating between members of the family. Through masturoh program, the Jama'ah Tabligh's family can study, learn, and understand deeply the duties and obligations of husband and wife. It starts with a sholehah wife, who obeys her husband and educates their children. Every couple must support and help each other in performing their duties and obligations, such as the preaching obligation for husbands and following masturoh for wives. From explanation above, we know that Jama'ah Tabligh's family inclines to Religious Ministry Affair. We can identify it when the parents choose the education for their children and prioritize praying together, the hereafter is more important than this world. For example, a husband must prioritize preaching over work anytime. The purpose it is to spread Islamic religion by their soul and their wealth in God's way.

From some opinion of subjects, we know that the primary duty of a wife is as a mother. The mother is the first schooling for her children, so her duty is to educate her children and manage the household in creating the next quality generation to be able to continue their parents preaching in spreading, inviting and teaching the Muslim community to worship God, do the obligations and sunnah deeds and prioritize religion preaching. The subjects' families are simple families with no extravagances. They imitate and emulate the prophet's life who lived in a simple and adequate fashion and was more focused on the importance of the hereafter. They have a decent place to live simply and reasonable that is resided by a member of family. Then, they pay attention to their family members' health. If one of them is sick then another family member can give medicine, read some verses of the Holy Koran in front of water and check up with the doctor. Their lives are simple and harmonious. The members of the family remind each other about their duties and obligations. As parents, they will teach their children to love giving sadaqah and performing the qurban.

Then, they always help others who need help. The efforts of Jama'ah Tabligh in creating a Sakinah Family are by giving religious education early to children, following masturoh for wife to learn religious knowledge deeply and the khuruj fi sabilillah program for husbands, thickening the faith, keeping communication between the members of a family, discussing, Jurisdictie: Jurnal Hukum dan Syariah Vol. 6 No. 2 Desember 2015 
practicing theobligatory andsunnah deeds and being more charitable. Husbands have a duty to preach, doing khuruj fi sabilillah for 3 days, 40 days, 6 months up to one year. To make a sakinah family, a family has obstacle factors and supporting factors. There are some obstacles factors in creating a sakinah family, they are : a. Lust/desire; b. The understanding family of husband or wife who are still worldly; c. Being excommunicated from family, neighbors and the community. While some supporting factors, include: a. Strengthening of faith, praying together, practicing the sunah deeds of the Prophet. b. Supporting of husband or wife's family when choosing an education for their children in material or non-material things. c. Following the sunnah of Prophet and living simply. d. Having a feeling to receive and be patient. e. Understanding religion as well. In general, the concept of a sakinah family that is applied by Jama'ah Tabligh is not much different from other concepts of family by Muslim societies. Jama'ah Tabligh does not have any specific arrangement details on how to build a sakinah family, because that concept is based on Islamic concepts that imitate the Prophet's family and are based on Fadhailul 'Amal book. However, the Jama'ah Tabligh family is a preaching family and to build sakinah family they are based on preaching values. The main consideration of marriage are to create a sakinah family, build the $d a$ 'wah, and form their next generation to be a preaching generation who always practices the obligations and sunnah deeds then they always keep their devotion and worship.

\section{Conclusion}

Based on previous explanation, it can be concluded that the family of Jama'ah Tabligh falls into the category of KS III level, which they can fulfill the basic needs, spiritual needs and the social-psychology needs but it cannot be a good model for society (The Ministry of Religious Affair). According to BKKBN, they are included as KS II because they are able to fulfill the basic needs, and social-psychology needs, but they are not able to fulfill the development needs. A sakinah family is formed because of the religious. understanding of Jama'ah Tabligh's ideology, preaching program (khuruj fi sabilillah for husband while masturoh program for wife) as well as the practice of the obligations and sunnahdeeds. The conclusion of some explanations in the previous chapter are as follows: (1) A sakinah family concept is based on Jama'ah Tabligh is a family that is led by a husband who works in religious preaching sincerely, always does the commands of God and Sunnah of Prophet and the members of the family always support and remember each other in religious things; (2) The efforts that were done by them in creatinga sakinah family are giving religious education to their children, strengthening the faith, practicing deeds, and implementing a khuruj fi sabilillah program for the husband anda masturoh program for the wife regularly. They always keep communication between the husband and wife, and the discussion becomes the best problem solver. The members of the family must be able to keep Sunnah and others deeds such as the obligatory deeds like doing dzikr, reciting, reading the important surah, reading surah Yasin in the morning and implementing the duties and obligations as a husband and wife especially in educating children and always istiqomah in charity.

\section{Bibilography}

Abdullah, Abdul Rahman Haji. Pemikiran Islam Di Malaysia: Sejarah dan Aliran. Jakarta: Gema Insani, 1997.

Al-Atsari, Abu Salma. "Studi Kritis Pemahaman Jama"ah Tabligh Dan Kitab Taghlibi Nisab.” Accessed December 7, 2012. http://varyd.wordpress.com/membongkarkedok-jamaah-tabligh-2/.

Cholil, Mufidah. Psikologi Keluarga Islam Berwawasan Gender. Malang: UIN-Malang Press, 2013.

Jurisdictie: Jurnal Hukum dan Syariah Vol. 6 No. 2 Desember 2015 
Hidayati, Nur. "Konsep Keluarga Sakinah Perspektif Aktivis Hizbut Tahrir Malang." Magister Thesis, UIN Maulana Malik Ibrahim Malang, 2009.

Iraqi, Butsainah al-Sayyid al-. 1000 Cara Membahagiakan Suami Istri. Translated by Ahmad Saminto and Mustofa. Yogyakarta: Mitra Pustaka, 2006.

Kalyakut, Sayyid Ahmad Syihab al-Din qadi. Menyingkap Tabir Jamaah Tabligh. Translated by Teungku H. Hasanoel Bashry. Yogyakarta: Diandra Primamitra Media, 2008.

Khusyt, Muhammad Ustman al-. Membangun Harmonisme Keluarga. Translated by Lembaga Penerjemah Penulis MuslimIndonesia. Jakarta: Qisthi Press, 2007.

Muhammad, Husein. Fiqh Perempuan Refleksi Kiai Atas Wacana Agama Dan Gender. Yogyakarta: LKiS, 2007.

Mushoffa, Aziz. Untaian Mutiara Buat Keluarga. Yogyakarta: Mitra Pustaka, 2001.

Nidha, Kiswatun. "Konsep Keluarga Sakinah Menurut Jama"eah Tabligh Perspektif Hukum Islam." Accessed December 17, 2012.

http://teosufi.webs.com/apps/blog/show/14112493-konsep-keluarga-sakinah-menurutjama-ah-tabligperspektif-hukum-islam-,.

Syahatah, Husain, and Faisal Asdar Bakri. Tanggung Jawab Suami Dalam Rumah Tangga. 1st ed. Jakarta: Media Grafika, 2005. 